\title{
Effect of Reflexotherapy on Controlling Primary Dysmenorrhea among Faculty Nursing Students
}

Shimaa Mohmed Zaky Hashem: Assistant lecturer of Maternity and Gynecological Nursing Faculty of Nursing, Tanta University

Manal Hassan Ahmed: Professor of Maternity and Gynecological Nursing Faculty of Nursing, Tanta University

Nevertity Hassan Zaky: Assistant Professor of Maternity and Gynecological Nursing Faculty of Nursing, Alexandria University

Azza Fouad El-Adham :Lecturer of Maternity and Gynecological Nursing

Faculty of Nursing, Tanta University

\begin{abstract}
Primary dysmenorrhea is the most common gynecologic disorder among female adolescents, with a prevalence of $60 \%$ to $93 \%$. It leads to several problems in the personal and social life of the female adolescents. Adverse effects of medical treatments and its failure rate of $20-25 \%$ have caused many females to seek other complementary and alternative methods for the management of primary dysmenorrhea. Reflexotherapy is one of such methods. So, the aim of this study was to determine the effect of reflexotherapy on controlling primary dysmenorrhea among Faculty Nursing Students. The study was conducted at Faculty Nursing, Tanta University. The total number of study sample was 120 female students from the second year of Faculty Nursing Students who fulfilling the inclusive criteria. Four tools were used for the collection of data: Tool I: Sociodemographic and menstrual history structured interview schedule. Tool II, Visual Analog Scale (VAS). Tool III, Modified McGill Pain Questionnaire Short form (MPQ-SF). Tool IV, Physiological and behavioral responses to pain sheet. The results of this study revealed that after the application of reflexotherapy, the intensity of menstrual pain had a significant decrease among the study group compared to the control group $1^{\text {st }}, 2^{\text {nd }}$ and $3^{\text {rd }}$ months post intervention, as well as the intensity of sensory and affective menstrual pain descriptors. In addition the physiological and behavioral responses to menstrual pain were significantly improved. Therefore, the study recommended that reflexotherapy can be used in the management of primary dysmenorrhea and menstruation-related symptoms as this method is noninvasive, easy to perform, and free from the potentially adverse effects of analgesics.
\end{abstract}

Key words: primary dysmenorrhea, reflexotherapy and reflexology. 


\section{Introduction}

Primary dysmenorrhea is one of the most prevalent gynecologic problems among $60 \%$ to $93 \%$ of female adolescents ${ }^{(1)}$.Although primary dysmenorrhea is not a real threat to life, yet it is associated with various physical and psychological symptoms that can disrupt the quality of females' life at school, college and work. This results in sickness absenteeism, loss of academic hours that negatively affect the academic performance, as well as interfere with social interactions leading to isolation and loneliness ${ }^{(2-3)}$. Primary dysmenorrhea is defined as painful menstruation without identifiable pelvic pathology occurring when ovulatory menstrual cycle is established. It is characterized by spasmodic menstrual cramps that begin just a few hours before or with the onset of menstrual flow. This pain is most intense on the first or second day of menstrual flow. It is suprapubic in location with radiation into the inner aspects of the thighs ${ }^{(3-5)}$.

Menstrual cramps are often accompanied by other biologic symptoms including nausea, vomiting, loss of appetite, diarrhea, backaches, headaches, leg aches, weakness, tiredness, sweating, sleeplessness, frequency of urination, flushing, irritability, nervousness, fatigue or dizziness. Symptoms occur just before or during the menses, peak with the heaviest menstrual flow and usually last less than one day ${ }^{(6-7)}$. Non steroidal anti- inflammatory drugs (NSAIDs) are the first therapy of choice in patients with primary dysmenorrhea. However, these methods are not acceptable for long-term therapy due to their side effects ${ }^{(8-9)}$. Moreover, it has been reported that NSAIDs fail to alleviate menstrual pain in about $20 \%$ of women ${ }^{(10)}$. So, it seems necessary to provide nonpharmacological measures for such patients who don't respond to medication or suffer from its side effects and are not willing to consume drugs $^{(11)}$.

Reflexotherapy is used widely as one of the non-pharmacological pain management techniques. It is effective in reducing pain, fatigue, stress and tension, as well as improving the sense of well-being and quality of life ${ }^{(12-3)}$.Reflexotherapy is the systematic application of pressure techniques to reflex points on the feet, hands, or ears to produce specific effects in other parts of the body. Reflexotherapy is based on the premise that these reflex areas correspond with all body parts and reflect an image of the entire body (including organs, muscles, nerves, glands, and bones) in exactly the same order and position as in the body. This ancient therapeutic art of foot massage offers a way to release the flow of vital energy or Qi, a limitless source of healing energy, and restore the body balance, harmony, and health ${ }^{(14-6)}$. In addition reflexotherapy induces sense of relaxation, comfort, promotes proper blood 
circulation carrying fresh oxygen and food throughout the body, stimulates the immune system, encourages the release of toxins and breaks up deposits which may interfere with the flow of the body's electrical energy in the nervous system. All in all, reflexotherapy is a simple, safe, and inexpensive non-pharmacological method for pain relief in primary dysmenorrhea that nurses can use as a standard of care before moving to the pharmacological intervention $^{(17)}$

\section{Aim of the study}

The aim of this study was to determine the effect of reflexotherapy on controlling primary dysmenorrhea among Faculty Nursing Students.

\section{Research hypothesis}

Students with primary dysmenorrhea who receive reflexotherapy will exhibit less dysmenorrheal pain than those who do not receive the same intervention.

\section{Subjects and method}

\section{Research design:}

A quasi experimental research design was used in this study.

\section{Setting:}

The study was carried out at Faculty of Nursing at Tanta University.

\section{Subjects:}

According to the equation of power analysis, the study comprised a purposive sample of 120 second year female students selected from the above mentioned setting according to the following criteria:

Age from 17- 22 years, Not married, Have regular menstrual cycle that lasts from 21 to 35 days (interval of menstruation), Duration of menstrual cycle ranging from 3 to 7 days of blood flow, Have primary dysmenorrhea with moderate or severe degree according to Visual Analog Scale, Have normal body mass index, Don't use any drugs or physical methods (exercises) to relieve pain during the study period, Free from any systemic or gynecologic diseases, Free from any foot damaged tissues, arthritis, phlebitis, open wound, injuries, inflammation, and eczema, Willing to participate in the study.

The sample was divided randomly into two equal subgroups of 60 female students,

The study group: on which reflexotherapy was conducted.

The control group: who use their usual habits but don't use any medications to relief pain.

\section{Tools of data collection:}

Four tools were used for data collection:

Tool I: Socio-demographic and menstrual history structured interview schedule:

It was developed and used by the researcher to collect data about:

\section{Socio-demographic characteristics:} included age, height, weight, body mass index (it was estimated by the following equation: body mass index $=$ weight in 
$\mathrm{KG} /$ height $^{2}$ in $\mathrm{m}$ ), residence, telephone number, and E-mail.

2. Menstruation characteristics included age at menarche, menstrual interval, duration of blood flow, amount of menstrual bleeding by counting number of saturated pads per day.

3. Dysmenorrhea pain characteristics: included association of pain with menstruation, start time, degree, time of starting the present menstrual pain, site, radiation, and any previous or current methods used to relieve dysmenorrhea.

\section{Tool II: Visual Analog Scale (VAS):}

Visual Analog Scale was developed by Johanson F et al 1988, and was adopted by researcher to measure the intensity of pain. It consisted of a horizontal line in centimeters from 0 to 10 with two opposing extremes at each end; i.e. "no pain" and "worst possible pain" respectively. The student was asked to put a mark on the line indicating her pain intensity. This mark was then measured in $\mathrm{cm}$ from no pain to an extreme pain end to obtain the student's score. Descriptive terms, such as no pain was given a score of $(0)$, while mild pain was given a score of (1-3), moderate pain (4-6) and severe pain (7-10).

Tool III: Modified McGill Pain Questionnaire Short form (MPQ-SF): A modified version of McGill Pain
Questionnaire Short form was adopted from AbdElhaleem S., 2013, ${ }^{(18)}$. It was used to measure characteristics of pain. This tool consisted of two parts:

Part (I) Sensory pain descriptors: descriptors 1- 11 represented the sensory pain experience, included: throbbing, shooting, stabbing, sharp, cramping, gnawing, hot/ burning, aching, heavy, tender, and splitting.

Part (II) Affective pain descriptors: descriptors 12-15 represented the affective pain dimension included tiring/exhausting, sickening, fearful, and cruel/punishing.

Each descriptor was ranked on an intensity scale of $0=$ none, $1=$ mild, $2=$ moderate, $3=$ severe. Three pain scores were derived from the sum of the intensity rank values of the words chosen for sensory, affective, and total descriptors. The total score was the summation of scores from sensory and affective domains and the maximum value was 45 score which indicate the worst pain and the minimum value was 15 score which indicate mild pain. The total score was sub classified as follow:

- $0=$ no pain $1: 15=$ mild pain

- 16: $30=$ moderate pain31: $45=$ severe pain

\section{Tool IV: Physiological and behavioral}

responses to pain sheet:

This tool was adopted from Belal GH., $\mathbf{2 0 0 6}^{(19)}$. It consisted of two parts: 
Part(I) Physiological responses to pain, it was included gastrointestinal tract responses (nausea, vomiting and bowel discomfort), skin responses (skin color changes and diaphoresis), musculoskeletal responses (muscle pain), and nervous system responses (headache, fatigue, fainting and insomnia). These responses were checked for either presence or absence.

Part(II) Behavioral responses to pain: namely Postures included (relaxed muscles, guarded position or rubbing \& supporting body parts, and tense body postures), Gross motor included (quite, slightly restless, and very restless), Facial expressions included (no frowning or grimacing, some frowning or grimacing, and constant frowning or grimacing), and Verbal expressions included (making normal or no sounds, groans, moans, and cries out or sobs). For each of these four major behavioral, one of three alternative choices were elicited. A scoring of the choice was a 3 points rating scale with a minimum or "no pain" score of 0 and a maximum score of 12 . Statistically, this score was translated to the corresponding pain intensity as follow: no pain (0), mild (1-3), moderate (4-6), severe (7-8), and unbearable $(\geq 12)$.

\section{Method}

1. An official letter from the responsible authorities in the Faculty of Nursing was obtained to conduct the study.
2. Tool (I) was developed by the researcher after reviewing relevant and current literature. It was tested for its content and face validity by a jury of 5 experts in the field of Maternity and Gynecological Nursing. The face validity of the tool was calculated based on experts' opinion after calculating content validity index (\%) of its items and it was $92.8 \%$.

3. To assess reliability, the study tool was tested by the pilot subjects at first session and retested after 2 weeks as test-retest reliability for calculating Cronbach's Alpha which was 0.875 .

4. A pilot studywas carried out on $10 \%$ of the total sample (12 students who were excluded from the sample). After conducting the pilot study, few words had been modified and the tool was made ready for use.

5. The total number of the female students of the second year at the beginning of the first semester of academic year (2015) was 458 female students. All of those students were first screened by socio-demographic and menstrual history structured interview schedule regarding their characteristics of primary dysmenorrhea and Visual analogue scalealsoto estimates the prevalence of primary dysmenorrhea (Tool I, II). Out of those,392students 
had primary dysmenorrhea, 120 female students who fulfill the study criteria were divided randomly into two equal subgroups (study group and control group), 60 students in each group.

6. The study group:(reflexotherapy group) was divided into small subgroups (10 students in each). Those students received detailed explanation on essential knowledge about primary dysmenorrhea including: definition, causes, risk factors, associated symptoms, and its management especially the effect of reflexotherapy in relieving pain. In addition, an interactive training session was applied to each student in the subgroup separately about conducting reflexotherapy technique when complaining of moderate or severe pain at home; demonstration of the technique was done by the researcher and re demonstration by each student was carried out in front of the researcher more than one time to ensure their ability to do the technique correctly. The students were also trained on the use of tool II, tool III and tool IV.

7. Reflexotherapy was applied to the study group either by the researcher or by the students at home depending on the actual time of their menstrual painduring the first two days of menstruation for 40 minutes (20 minutes per foot) in the form of two sessions one session on the first day and the another session on the second day of menstruation for three consecutive menstrual cycles. The researcher instructed the students to stop the use of any pain relieve measure at this time except reflexotherapy technique.

8. Reflexotherapy technique was applied to the students' feet using the thumb, index and hands. The researcher followed 4 steps; step one was relaxation exercises to loosen the feet up, step two was thump walking up and down the spine area of the feet for back pain, step three was softly thumb walk the top/back of the feet for groin pain, and step four was thumb walk the reflex points of pituitary gland, solar plexus, liver, spleen, stomach, intestinal area, uterus, ovaries, and fallopian tubes areas of the feet for abdominal pain.

9. The control group: used their usual habits but didn't use any medications to relief pain. The students were also trained on how to use of tool II, tool III and tool IV.

10. The participants were asked to put a mark on the line indicating their perceived intensity of dysmenorrhea using the Visual Analogue Scale (Tool II) before the interventions (at the onset 
of menstrual pain) and immediately after the interventions and at the end of the first and second days of menstruation for the three menstrual cycles. The score was determined by measuring the distance from the "no pain" end to the location marked by participants.

11. Modified McGill pain questionnaire short form (MPQ-SF) (sensory and affective pain descriptors) (Tool III) \& physiological and behavioral responses to pain sheet (Tool IV) were used and assessed before the interventions (at the onset of menstrual pain) and immediately after the interventions and at the end of the first and second days of menstruation for the three menstrual cycles.

\section{Statistical analysis}

The collected data were organized, tabulated and statistically analyzed using SPSS software (Statistical Package for the Social Sciences, version 16, SPSS Inc. Chicago, IL, USA).

\section{Results}

Figure (1): Reveals that the prevalence rate of primary dysmenorrhea was $85.6 \%$ among all students of the second year Faculty Nursing students at Tanta University.

Table (1): Clarifies the socio-demographic characteristics of the study and control groups. It was observed that the mean age of the study group was $19.90 \pm 0.35$ years corresponding to a mean age of $20.03 \pm 0.45$ years among the control group, approximate percentage of study (75\%) and control groups $(66.7 \%)$ respectively were from rural areas and that both the study and control groups $\left(24.17 \pm 4.05 \mathrm{~kg} /\right.$ meter $^{2} \& 24.07 \pm 3.22$ $\mathrm{kg} /$ meter $^{2}$ respectively) have normal body mass index.

Table (2): Presents the percent distribution of students regarding their menstrual history. It was noticed that there was equal percentage of study and control group $(58.3 \%)$ had menarche at $13-<15$ years, (58.3\% \&55\% respectively) of the study and the control group had an interval of $>27$ 35days, (61.7\% and 63.3 respectively) of study and control groups had duration of menstrual blood flow ranged from $>5-7$ days, and (68.3\% and 61.7 respectively) of the study and control groups described the amount of their menstrual blood loss as moderate (2-3towels/day).

Table (3): Illustrates the menstrual pain characteristics among the study and control groups. It was observed that $(33.3 \%)$ of the study group and (38.3\%) of the control group had reported that first menstrual pain was felt after 6 months from the first menstrual cycle, convergent percent of study and control groups $(61.7 \%$ and $66.7 \%$ respectively) had severe degree of menstrual pain, $(60.0 \%$ and $63.3 \%$ respectively) of 
both study and control groups had reported that the pain was started with the onset of menstruation and continue for 48 hours, $(63.3 \%)$ of the study group and $(55.0 \%)$ of the control group felt menstrual pain on lower abdomen, whereas, $(45.0 \%$ and $41.7 \%$ respectively) of both study and control groups had reported that menstrual pain radiated to multiple sites like their lower back and legs. The table also revealed the different methods utilized by students to alleviate their menstrual pain considering bed rest is the common relieving methods among students of both the study and the control groups $(83.3 \%$ and $78.3 \%$ respectively).

Figure (2): Displays the mean scores of VAS were $(7.25,7.08$ and 6.93 respectively) among the study group compared to (7.62, 7.48 and 7.13 respectively) among the control group pre intervention. However $1^{\text {st }}$, $2^{\text {nd }}$ and $3^{\text {rd }}$ months post intervention there was a significant decrease in the mean scores of VAS among the study group compared to the control group especially at the end of the second day after reflexotherapy. This was so marked $3^{\text {rd }}$ month post intervention where the mean score was decreased to (1.85) among the study group compared to (4.62) among the control group.

Table (4): reveals that the total pain intensity scores of sensory and affective menstrual pain descriptors according to (MPQ-SF) were severe among (75.0\%, $70.0 \%$ and $73.3 \%$ respectively) of the study group compared to $(78.3 \%, 80.0 \%$ and $76.7 \%$ respectively) of the control group pre intervention at the first, second and third months respectively with no statistically significant differences $(\mathrm{P}=0.875,0.420 \&$ 0.900). On the other hand, there was a significant decrease of pain sensation among (35.0\%, $40.0 \%$ and $46.7 \%$ respectively) of the study group compared to $(0 \%, 0 \%$ and $5.0 \%$ respectively) among the control group $1^{\text {st }}, 2^{\text {nd }}$ and $3^{\text {rd }}$ months post intervention especially at the end of the second day after reflexotherapy, with statistically significant difference $(\mathrm{P}=0.009,0.0002 \& 0.0001)$.

Table (5): Shows that nausea, muscle pain, headache and fatigue were reported as the most common physiological responses to menstrual pain among (60\%, 71.7\%,76.7\% and $75.0 \%$ respectively) of the study group compared to $(61.7 \%, 75.0 \%, 85.0 \%$ and $60.0 \%$ respectively) of the control group pre intervention. While, the table points statistically significant improvement in students physiological responses to menstrual pain $1^{\text {st }}, 2^{\text {nd }}$ and $3^{\text {rd }}$ months post intervention among the study group compared to the control group. This improvement was so marked $3^{\text {rd }}$ month post intervention especially at the end of the second day after reflexotherapy among the 
study group compared to the control group. Where nausea, muscle pain, headache and fatigue were significantly reduced to $(10.0 \%, 16.7 \%, 13.3 \%$ and $21.7 \%)$ among the study group compared to only $(46.7 \%, 50.0 \%, 60.0 \%$ and $51.7 \%)$ among the control group with statistically significant difference $(\mathrm{P}=0.0001)$.

Table (6): Elucidates that the total score levels of behavioral response to menstrual pain were moderate among $(90.0 \%, 90.0 \%$ and $83.3 \%$ respectively) of the study group compared to $(88.3 \%, 88.3 \%$ and $85.0 \%$ respectively) of the control group pre intervention at the first, second and third months respectively with no statistically significant differences $(\mathrm{P}=0.690,0.702 \&$ 0.494). On the other hand, there was a significant decrease of pain sensation among (20.0\%, 33.3\% and $36.7 \%$ respectively) of the study group compared to equal percentage of $(0 \%)$ among the control group $1^{\text {st }}, 2^{\text {nd }}$ and $3^{\text {rd }}$ months post intervention especially at the end of the second day after reflexotherapy, with statistically significant difference $(\mathrm{P}=0.0001)$. 
Figure (1): Prevalence rate of primary dysmenorrhea among the second year Faculty Nursing students $(n=458)$.

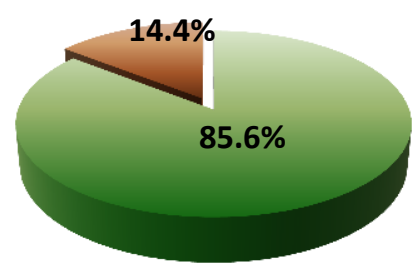

Primary dysmenorrhea $(n=392)$

Table (1): Percent distribution of students regarding their socio-demographic characteristics .

\begin{tabular}{|c|c|c|c|c|c|}
\hline \multirow[t]{2}{*}{$\begin{array}{c}\text { socio-demographic } \\
\text { characteristics }\end{array}$} & \multicolumn{2}{|c|}{$\begin{array}{l}\text { Study group } \\
\qquad(n=60)\end{array}$} & \multicolumn{2}{|c|}{$\begin{array}{c}\text { Control group } \\
\qquad(\mathrm{n}=60)\end{array}$} & \multirow[t]{2}{*}{$\begin{array}{c}\text { t-test } \\
P\end{array}$} \\
\hline & $\mathbf{n}$ & $\%$ & $\mathbf{n}$ & $\%$ & \\
\hline \multicolumn{6}{|l|}{ - Age years: } \\
\hline Range & \multicolumn{2}{|c|}{ 19-21 } & \multicolumn{2}{|c|}{ 19-21 } & 1.804 \\
\hline Mean \pm SD & \multicolumn{2}{|c|}{$19.90 \pm 0.35$} & \multicolumn{2}{|c|}{$20.03 \pm 0.45$} & 0.074 \\
\hline \multicolumn{6}{|l|}{ - Residence: } \\
\hline Rural & 45 & 75.0 & 40 & 66.7 & \\
\hline Urban & 15 & 25.0 & 20 & 33.3 & \\
\hline$\chi^{2}$ & \multicolumn{4}{|c|}{0.650} & \\
\hline $\mathbf{P}$ & \multicolumn{4}{|c|}{0.422} & \\
\hline \multicolumn{6}{|l|}{ - Body weight (kg): } \\
\hline Range & \multicolumn{2}{|c|}{$45-85$} & \multicolumn{2}{|c|}{$42-88$} & 0.609 \\
\hline Mean \pm SD & \multicolumn{2}{|c|}{$60.64 \pm 9.57$} & \multicolumn{2}{|c|}{$61.70 \pm 9.46$} & 0.544 \\
\hline \multicolumn{6}{|l|}{ - Height (cm): } \\
\hline Range & \multicolumn{2}{|c|}{$130-170$} & \multicolumn{2}{|c|}{$140-178$} & 1.027 \\
\hline Mean \pm SD & \multicolumn{2}{|c|}{$158.65 \pm 7.50$} & \multicolumn{2}{|c|}{$160.03 \pm 7.24$} & 0.306 \\
\hline \multicolumn{6}{|l|}{ - Body mass index (BMI): } \\
\hline Range & \multicolumn{2}{|c|}{$17.58-40.43$} & \multicolumn{2}{|c|}{$18.52-33.53$} & 0.159 \\
\hline Mean \pm SD & \multicolumn{2}{|c|}{$24.17 \pm 4.05$} & \multicolumn{2}{|c|}{$24.07 \pm 3.22$} & 0.874 \\
\hline
\end{tabular}


Table (2): Percent distribution of students regarding their menstrual history

\begin{tabular}{|c|c|c|c|c|c|}
\hline \multirow[t]{2}{*}{ menstrual history } & \multicolumn{2}{|c|}{$\begin{array}{l}\text { Study group } \\
\quad(\mathrm{n}=60)\end{array}$} & \multicolumn{2}{|c|}{$\begin{array}{l}\text { Control group } \\
(\mathbf{n}=\mathbf{6 0})\end{array}$} & \multirow[t]{2}{*}{$\begin{array}{l}\chi^{2} \\
\mathbf{P}\end{array}$} \\
\hline & $\mathbf{n}$ & $\%$ & $\mathbf{n}$ & $\%$ & \\
\hline \multicolumn{6}{|l|}{ - Age years of menarche: } \\
\hline$-9-<11$ & 3 & 5.0 & 6 & 10.0 & \multirow{8}{*}{$\begin{array}{l}3.066 \\
0.382\end{array}$} \\
\hline$-11-<13$ & 13 & 21.7 & 15 & 25.0 & \\
\hline$-13-<15$ & 35 & 58.3 & 35 & 58.3 & \\
\hline$-15-17$ & 9 & 15.0 & 4 & 6.7 & \\
\hline Range & \multirow{2}{*}{\multicolumn{2}{|c|}{$\begin{array}{c}10-17 \\
12.95 \pm 1.90\end{array}$}} & \multicolumn{2}{|c|}{$9-16$} & \\
\hline Mean \pm SD & & & \multicolumn{2}{|c|}{$12.73 \pm 1.63$} & \\
\hline t-test & \multicolumn{4}{|c|}{0.671} & \\
\hline $\mathrm{P}$ & \multicolumn{4}{|c|}{0.504} & \\
\hline \multicolumn{6}{|l|}{$\begin{array}{l}\text { - Interval of menstrual cycle } \\
\text { (days): }\end{array}$} \\
\hline$-21-27$ & 25 & 41.7 & 27 & 45.0 & \multirow{6}{*}{$\begin{array}{l}0.136 \\
0.713\end{array}$} \\
\hline$->27-35$ & 35 & 58.3 & 33 & 55.0 & \\
\hline Range & \multirow{2}{*}{\multicolumn{2}{|c|}{$\begin{array}{c}24-35 \\
29.08 \pm 3.80\end{array}$}} & \multicolumn{2}{|c|}{$20-35$} & \\
\hline Mean $\pm \mathrm{SD}$ & & & \multicolumn{2}{|c|}{$27.78 \pm 3.86$} & \\
\hline t-test & \multicolumn{4}{|c|}{1.855} & \\
\hline $\mathrm{P}$ & \multicolumn{4}{|c|}{0.066} & \\
\hline \multicolumn{6}{|l|}{$\begin{array}{l}\text {-Duration of menstrual blood } \\
\text { flow (days): }\end{array}$} \\
\hline$-3-5$ & 23 & 38.3 & 22 & 36.7 & \multirow{6}{*}{$\begin{array}{l}0.000 \\
1.000\end{array}$} \\
\hline$->5-7$ & 37 & 61.7 & 38 & 63.3 & \\
\hline Range & \multirow{2}{*}{\multicolumn{2}{|c|}{$\begin{array}{c}3-7 \\
5.07 \pm 1.09\end{array}$}} & \multirow{2}{*}{\multicolumn{2}{|c|}{$\begin{array}{c}3-7 \\
4.78 \pm 1.38\end{array}$}} & \\
\hline Mean \pm SD & & & & & \\
\hline t-test & \multicolumn{4}{|c|}{1.250} & \\
\hline $\mathrm{P}$ & \multicolumn{4}{|c|}{0.214} & \\
\hline \multicolumn{6}{|l|}{$\begin{array}{l}\text {-Amount of menstrual blood } \\
\text { loss (No. of towels/ days): }\end{array}$} \\
\hline - Light (one towel daily) & 8 & 13.3 & 10 & 16.7 & 0.594 \\
\hline - Moderate (2-3 towels daily) & 41 & 68.3 & 37 & 61.7 & 0.743 \\
\hline - Severe ( $4 \&$ more towels daily) & 11 & 18.3 & 13 & 21.7 & \\
\hline
\end{tabular}

\footnotetext{
*Significant $(\mathbf{P}<0.05)$
} 
Table (3): Percent distribution of students regarding their menstrual pain characteristics

\begin{tabular}{|c|c|c|c|c|c|c|}
\hline \multirow[t]{2}{*}{ menstrual pain characteristics } & \multicolumn{2}{|c|}{$\begin{array}{l}\text { Study } \\
\text { group } \\
(n=60)\end{array}$} & \multicolumn{2}{|c|}{$\begin{array}{c}\text { Control } \\
\text { group } \\
(n=60)\end{array}$} & \multirow[t]{2}{*}{$\chi^{2}$} & \multirow[t]{2}{*}{$\mathbf{P}$} \\
\hline & $\mathbf{n}$ & $\%$ & $\mathbf{n}$ & $\%$ & & \\
\hline \multicolumn{7}{|l|}{ - Time of first menstrual pain: } \\
\hline -With first menstrual period & 3 & 5.0 & 4 & 6.7 & 4.585 & 0.205 \\
\hline -After 6 months from first menstruation & 20 & 33.3 & 23 & 38.3 & & \\
\hline -After one year from first menstruation & 20 & 33.3 & 10 & 16.7 & & \\
\hline -After two years from first menstruation & 17 & 28.3 & 23 & 38.3 & & \\
\hline \multicolumn{7}{|l|}{ - Intensity of menstrual pain: } \\
\hline -Moderate pain & 23 & 38.3 & 20 & 33.3 & 0.326 & 0.568 \\
\hline -Severe pain & 37 & 61.7 & 40 & 66.7 & & \\
\hline \multicolumn{7}{|l|}{ - Time of menstrual pain occurrence: } \\
\hline -Directly before menstruation & 10 & 16.7 & 10 & 16.7 & 0.127 & 0.047 \\
\hline $\begin{array}{l}\text {-With onset of the menstrual period \& continue } \\
24 \text { hours }\end{array}$ & 14 & 23.3 & 12 & 20.0 & & \\
\hline $\begin{array}{l}\text {-With onset of the menstrual period \& continue } \\
48 \text { hours }\end{array}$ & 36 & 60.0 & 38 & 63.3 & & \\
\hline \multicolumn{7}{|l|}{ \#-Sites of menstrual pain occurrence: } \\
\hline -Lower abdomen & 38 & 63.3 & 33 & 55.0 & 0.862 & 0.353 \\
\hline -Lower back & 30 & 50.0 & 18 & 30.0 & 5.000 & $0.025 *$ \\
\hline -Lower limbs & 11 & 18.3 & 5 & 8.3 & 2.596 & 0.107 \\
\hline -All the above sites & 23 & 38.3 & 25 & 41.7 & 0.139 & 0.709 \\
\hline \multicolumn{7}{|l|}{ \#-Sites of menstrual pain radiation: } \\
\hline -Lower back & 15 & 25.0 & 22 & 36.7 & 1.915 & 0.166 \\
\hline -Front and back of the legs & 18 & 30.0 & 22 & 36.7 & 0.600 & 0.439 \\
\hline -Multiple sites & 27 & 45.0 & 25 & 41.7 & 0.136 & 0.713 \\
\hline \multicolumn{7}{|l|}{ \#-Methods for relieving menstrual pain : } \\
\hline -Warm liquids & 41 & 68.3 & 38 & 63.3 & 0.333 & 0.564 \\
\hline -Analgesics & 28 & 46.7 & 27 & 45.0 & 0.134 & 0.855 \\
\hline -Bed rest & 50 & 83.3 & 47 & 78.3 & 0.484 & 0.487 \\
\hline -Warming & 30 & 50.0 & 28 & 46.7 & 0.133 & 0.715 \\
\hline -Massage over the abdomen & 16 & 26.7 & 23 & 38.3 & 1.861 & 0.172 \\
\hline -Taking warm shower & 19 & 31.7 & 29 & 48.3 & 3.472 & 0.062 \\
\hline -Follow special diet regimen & 4 & 6.7 & 7 & 11.7 & 0.901 & 0.343 \\
\hline
\end{tabular}

$\chi^{2}$ : Chi-square test*Significant $(\mathbf{P}<0.05)$

\#: More than one answer was chosen 
Figure (2): Mean score of menstrual pain intensity among the studied students (study and control groups) according to Visual Analogue Scale (VAS) scores before and after reflexotherapy at three menstrual cycles

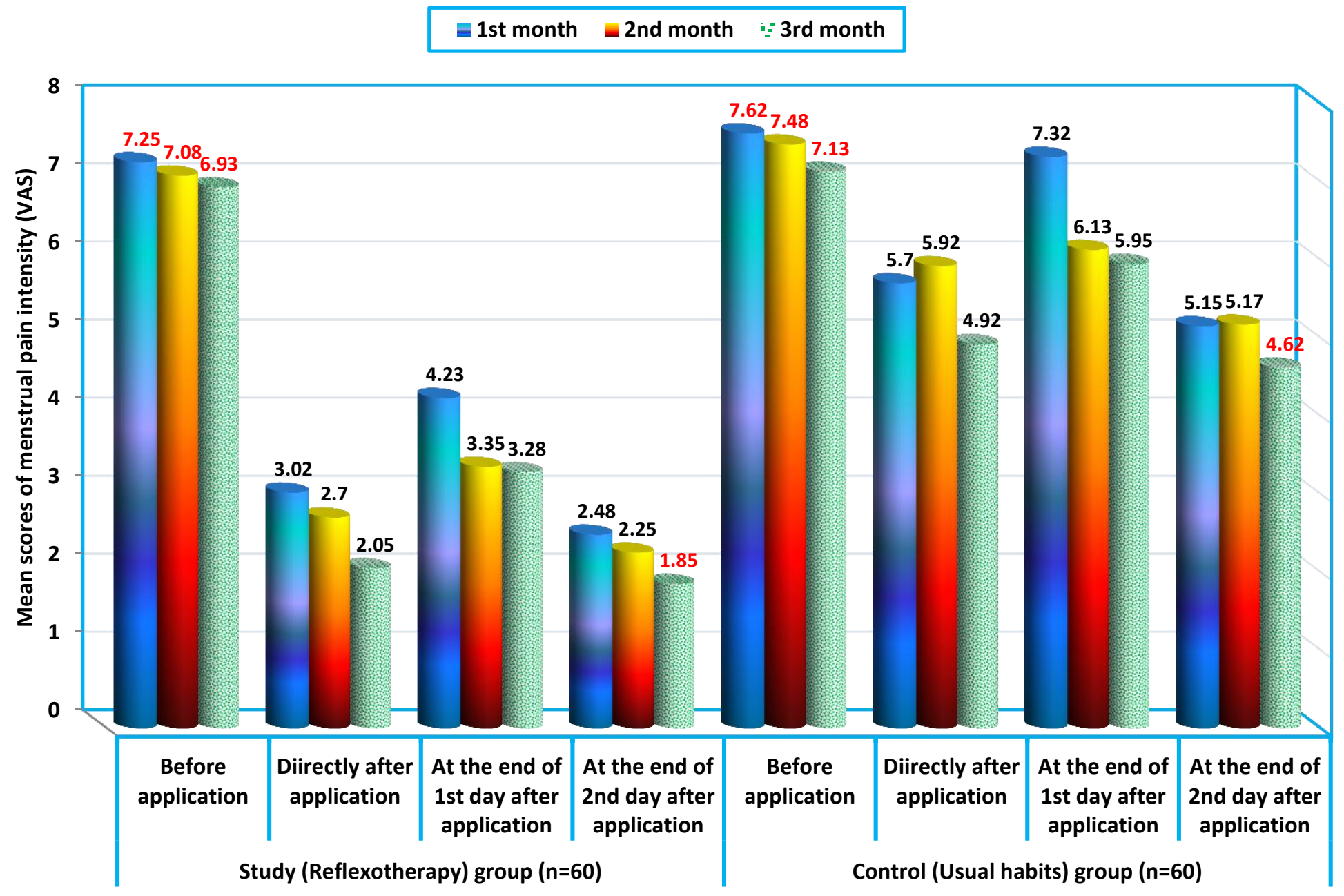


Table (4): Total score level ofsensory and affective menstrual pain descriptors among the studied students at three months of menstrual cycle before and after application of reflexotherapy.

\begin{tabular}{|c|c|c|c|c|c|c|c|c|c|c|c|c|c|c|c|}
\hline \multirow{4}{*}{$\begin{array}{l}\text { Levels of total sensory } \\
\text { and affective } \\
\text { menstrual pain } \\
\text { descriptors before and } \\
\text { after application }\end{array}$} & \multicolumn{12}{|c|}{$\begin{array}{l}\text { Total sensory and affective menstrual pain descriptors among the } \\
\text { studied students at three months of menstrual cycle } \\
\qquad(\mathrm{n}=120)\end{array}$} & \multirow{2}{*}{\multicolumn{3}{|c|}{$\begin{array}{c}\chi^{2} \\
\mathbf{P} \\
\text { (Study vs Control group) }\end{array}$}} \\
\hline & \multicolumn{6}{|c|}{$\underset{(\mathrm{n}=60)}{\text { Study group }}$} & \multicolumn{6}{|c|}{$\begin{array}{c}\text { Control group } \\
(\mathrm{n}=\mathbf{6 0})\end{array}$} & & & \\
\hline & \multicolumn{2}{|c|}{$\begin{array}{c}1^{\text {st }} \\
\text { month }\end{array}$} & \multicolumn{2}{|c|}{$2^{\text {nd }}$ month } & \multicolumn{2}{|c|}{$3^{\text {rd }}$ month } & \multicolumn{2}{|c|}{$\mathbf{1}^{\text {st }}$ month } & \multicolumn{2}{|c|}{$2^{\text {nd }}$ month } & \multicolumn{2}{|c|}{$3^{\text {rd }}$ month } & \multirow[t]{2}{*}{$\mathbf{1}^{\mathrm{st}}$ month } & \multirow[t]{2}{*}{$2^{\text {nd }}$ month } & \multirow[t]{2}{*}{$3^{\mathrm{rd}}$ month } \\
\hline & $\mathbf{n}$ & $\%$ & $\mathbf{n}$ & $\%$ & $\mathbf{n}$ & $\%$ & $\mathrm{n}$ & $\%$ & $\mathrm{n}$ & $\%$ & $\mathrm{n}$ & $\%$ & & & \\
\hline $\begin{array}{l}\text { Before application: } \\
- \text { Mild pain } \\
- \text { Moderate pain } \\
- \text { Severe pain }\end{array}$ & $\begin{array}{c}5 \\
10 \\
45\end{array}$ & $\begin{array}{c}8.3 \\
16.7 \\
75.0\end{array}$ & $\begin{array}{c}4 \\
14 \\
42\end{array}$ & $\begin{array}{c}6.7 \\
23.3 \\
70.0\end{array}$ & $\begin{array}{c}3 \\
13 \\
44\end{array}$ & $\begin{array}{c}5.0 \\
21.7 \\
73.3\end{array}$ & $\begin{array}{c}4 \\
9 \\
47\end{array}$ & $\begin{array}{c}6.7 \\
15.0 \\
78.3\end{array}$ & $\begin{array}{c}2 \\
10 \\
48\end{array}$ & $\begin{array}{c}3.3 \\
16.7 \\
80.0\end{array}$ & $\begin{array}{c}3 \\
11 \\
46\end{array}$ & $\begin{array}{c}5.0 \\
18.3 \\
76.7\end{array}$ & $\begin{array}{l}0.271 \\
0.875\end{array}$ & $\begin{array}{l}1.733 \\
0.420\end{array}$ & $\begin{array}{l}0.210 \\
0.900\end{array}$ \\
\hline $\begin{array}{l}\text { Directly after } \\
\text { application: } \\
-\quad \text { No pain } \\
- \text { Mild pain } \\
-\quad \text { Moderate pain } \\
-\quad \text { Severe pain }\end{array}$ & $\begin{array}{l}11 \\
28 \\
16 \\
5\end{array}$ & $\begin{array}{c}18.3 \\
46.7 \\
26.7 \\
8.3\end{array}$ & $\begin{array}{l}19 \\
24 \\
15 \\
2\end{array}$ & $\begin{array}{l}31.7 \\
40.0 \\
25.0 \\
3.3\end{array}$ & $\begin{array}{l}19 \\
31 \\
8 \\
2\end{array}$ & $\begin{array}{c}31.7 \\
51.7 \\
13.3 \\
3.3\end{array}$ & $\begin{array}{c}0 \\
20 \\
31 \\
9\end{array}$ & $\begin{array}{c}0 \\
33.3 \\
51.7 \\
15.0\end{array}$ & $\begin{array}{c}0 \\
13 \\
36 \\
11\end{array}$ & $\begin{array}{c}0 \\
21.7 \\
60.0 \\
18.3\end{array}$ & $\begin{array}{c}3 \\
12 \\
37 \\
8\end{array}$ & $\begin{array}{c}5.0 \\
20.0 \\
61.7 \\
13.3\end{array}$ & $\begin{array}{c}16.820 \\
0.0007^{*}\end{array}$ & $\begin{array}{c}35.761 \\
0.0001 *\end{array}$ & $\begin{array}{c}42.650 \\
0.0001^{*}\end{array}$ \\
\hline $\begin{array}{l}\text { At the end of } \mathbf{1}^{\text {st }} \text { day } \\
\text { after application } \\
-\quad \text { No pain } \\
-\quad \text { Mild pain } \\
-\quad \text { Moderate pain } \\
-\quad \text { Severe pain }\end{array}$ & $\begin{array}{c}9 \\
25 \\
21 \\
5\end{array}$ & $\begin{array}{c}15.0 \\
41.7 \\
35.0 \\
8.3\end{array}$ & $\begin{array}{c}15 \\
19 \\
24 \\
2\end{array}$ & $\begin{array}{c}25.0 \\
31.7 \\
40.0 \\
3.3\end{array}$ & $\begin{array}{c}15 \\
20 \\
24 \\
1\end{array}$ & $\begin{array}{c}25.0 \\
33.3 \\
40.0 \\
1.7 \\
\end{array}$ & $\begin{array}{c}0 \\
18 \\
32 \\
10 \\
\end{array}$ & $\begin{array}{c}0 \\
30.0 \\
53.3 \\
16.7 \\
\end{array}$ & $\begin{array}{c}0 \\
13 \\
37 \\
10\end{array}$ & $\begin{array}{c}0 \\
21.7 \\
61.7 \\
16.7\end{array}$ & $\begin{array}{c}0 \\
11 \\
42 \\
7 \\
\end{array}$ & $\begin{array}{c}0 \\
18.3 \\
70.0 \\
11.7\end{array}$ & $\begin{array}{l}11.370 \\
0.010^{*}\end{array}$ & $\begin{array}{c}22.520 \\
0.0001 *\end{array}$ & $\begin{array}{l}15.870 \\
0.001^{*}\end{array}$ \\
\hline $\begin{array}{l}\text { At the end of } 2^{\text {nd }} \text { day } \\
\text { after application } \\
-\quad \text { No pain } \\
-\quad \text { Mild pain } \\
-\quad \text { Moderate pain } \\
-\quad \text { Severe pain } \\
\end{array}$ & $\begin{array}{c}21 \\
25 \\
9 \\
5 \\
\end{array}$ & $\begin{array}{c}35.0 \\
41.7 \\
15.0 \\
8.3 \\
\end{array}$ & $\begin{array}{c}24 \\
19 \\
15 \\
2 \\
\end{array}$ & $\begin{array}{c}40.0 \\
31.7 \\
25.0 \\
3.3 \\
\end{array}$ & $\begin{array}{c}28 \\
20 \\
11 \\
1 \\
\end{array}$ & $\begin{array}{c}46.7 \\
33.3 \\
18.3 \\
1.7 \\
\end{array}$ & $\begin{array}{c}0 \\
19 \\
32 \\
9 \\
\end{array}$ & $\begin{array}{c}0 \\
31.7 \\
53.3 \\
15.0 \\
\end{array}$ & $\begin{array}{c}0 \\
11 \\
42 \\
7 \\
\end{array}$ & $\begin{array}{c}0 \\
18.3 \\
70.0 \\
11.7 \\
\end{array}$ & $\begin{array}{c}3 \\
12 \\
40 \\
5 \\
\end{array}$ & $\begin{array}{c}5.0 \\
20.0 \\
66.7 \\
8.3 \\
\end{array}$ & $\begin{array}{l}11.570 \\
0.009^{*}\end{array}$ & $\begin{array}{c}19.562 \\
0.0002 *\end{array}$ & $\begin{array}{c}25.941 \\
0.0001 *\end{array}$ \\
\hline
\end{tabular}


Table (5): Percent distribution of present physiological responses to menstrual pain among the studied students (study and control groups) at three menstrual cycles before and after reflexotherapy.

\begin{tabular}{|c|c|c|c|c|c|c|c|c|c|c|c|c|c|c|c|c|c|c|}
\hline \multirow{4}{*}{$\begin{array}{l}\text { Present physiological } \\
\text { responses before and after } \\
\text { reflexotherapy }\end{array}$} & \multicolumn{12}{|c|}{$\begin{array}{l}\text { Present physiological responses among the studied students at } \\
\text { three months of menstrual cycle } \\
\qquad(\mathrm{n}=120)\end{array}$} & \multirow{2}{*}{\multicolumn{6}{|c|}{$\begin{array}{c}\chi^{2} \\
P \\
\text { (Study vs Control group) }\end{array}$}} \\
\hline & \multicolumn{6}{|c|}{$\begin{array}{c}\text { Study group } \\
(\mathrm{n}=60)\end{array}$} & \multicolumn{6}{|c|}{$\begin{array}{c}\text { Control group } \\
(\mathbf{n}=\mathbf{6 0})\end{array}$} & & & & & & \\
\hline & \multicolumn{2}{|c|}{$\begin{array}{c}1^{\text {st }} \\
\text { month }\end{array}$} & \multicolumn{2}{|c|}{$\begin{array}{c}2^{\text {nd }} \\
\text { month }\end{array}$} & \multicolumn{2}{|c|}{$\begin{array}{c}3^{\text {rd }} \\
\text { month }\end{array}$} & \multicolumn{2}{|c|}{$\begin{array}{c}1^{\text {st }} \\
\text { month }\end{array}$} & \multicolumn{2}{|c|}{$\begin{array}{c}2^{\text {nd }} \\
\text { month }\end{array}$} & \multicolumn{2}{|c|}{$\begin{array}{c}3^{\text {rd }} \\
\text { month }\end{array}$} & \multirow{2}{*}{\multicolumn{2}{|c|}{$1^{\text {st }}$ month }} & \multirow{2}{*}{\multicolumn{2}{|c|}{$2^{\text {nd }}$ month }} & \multirow{2}{*}{\multicolumn{2}{|c|}{$3^{\text {rd }}$ month }} \\
\hline & $\mathbf{n}$ & $\%$ & $\mathbf{N}$ & $\%$ & $\mathbf{n}$ & $\%$ & $\mathbf{n}$ & $\%$ & $\mathbf{n}$ & $\%$ & $\mathbf{n}$ & $\%$ & & & & & & \\
\hline \multicolumn{19}{|l|}{-Nausea: } \\
\hline - Before application & 40 & 66.7 & 36 & 60.0 & 36 & 60.0 & 43 & 71.7 & 40 & 66.7 & 37 & 61.7 & 0.160 & 0.962 & 0.320 & 0.570 & 0.030 & 0.852 \\
\hline - Directly after application & 22 & 36.7 & 19 & 31.7 & 13 & 21.7 & 37 & 61.7 & 39 & 65.0 & 30 & 50.0 & 7.502 & $0.006^{*}$ & 13.348 & $0.0001 *$ & 10.474 & $0.001 *$ \\
\hline $\begin{array}{l}\text { - At the end of 1st day after } \\
\text { application }\end{array}$ & 22 & 36.7 & 17 & 28.3 & 12 & 20.0 & 27 & 45.0 & 30 & 50.0 & 30 & 50.0 & 0.862 & 0.363 & 5.911 & $0.015^{*}$ & 11.868 & $0.001 *$ \\
\hline $\begin{array}{l}\text { - At the end of 2nd day after } \\
\text { application }\end{array}$ & 22 & 36.7 & 11 & 18.3 & 6 & 10.0 & 23 & 38.3 & 26 & 43.3 & 28 & 46.7 & 0.036 & 0.850 & 8.792 & $0.003 *$ & 19.863 & $0.0001 *$ \\
\hline \multicolumn{19}{|l|}{ - Muscle Pain: } \\
\hline -Before application & 46 & 76.7 & 43 & 71.7 & 43 & 71.7 & 42 & 70.0 & 44 & 73.3 & 45 & 75.0 & 0.382 & 0.536 & 0.040 & 0.838 & 0.042 & 0.836 \\
\hline - Directly after application & 24 & 40.0 & 22 & 36.7 & 16 & 26.7 & 40 & 66.7 & 40 & 66.7 & 33 & 55.0 & 8.571 & $0.003 *$ & 10.812 & $0.001 *$ & 9.968 & $0.002 *$ \\
\hline $\begin{array}{l}\text { - At the end of 1st day after } \\
\text { application }\end{array}$ & 25 & 41.7 & 20 & 33.3 & 18 & 30.0 & 35 & 58.3 & 38 & 63.3 & 37 & 61.7 & 3.333 & 0.068 & 10.812 & $0.001 *$ & 12.117 & $0.0001 *$ \\
\hline $\begin{array}{l}\text { - At the end of } 2 \text { nd day after } \\
\text { application }\end{array}$ & 20 & 33.3 & 16 & 26.7 & 10 & 16.7 & 33 & 55.0 & 36 & 60.0 & 30 & 50.0 & 5.711 & $0.017^{*}$ & 13.575 & $0.0001 *$ & 15.000 & $0.0001 *$ \\
\hline \multicolumn{19}{|l|}{ - Fatigue: } \\
\hline - Before application & 41 & 68.3 & 43 & 71.7 & 45 & 75.0 & 38 & 63.3 & 42 & 70.0 & 43 & 71.7 & 0.153 & 0.700 & 0.040 & 0.840 & 0.042 & 0.836 \\
\hline - Directly after application & 23 & 38.3 & 23 & 38.3 & 15 & 25.0 & 37 & 61.7 & 36 & 60.0 & 31 & 51.7 & 6.533 & $0.011^{*}$ & 5.635 & $0.018 *$ & 9.025 & $0.003 *$ \\
\hline $\begin{array}{l}\text { - At the end of 1st day after } \\
\text { application }\end{array}$ & 23 & 38.3 & 23 & 38.3 & 18 & 30.0 & 35 & 58.3 & 33 & 55.0 & 33 & 55.0 & 4.805 & $0.028 *$ & 3.348 & 0.067 & 7.673 & $0.006^{*}$ \\
\hline $\begin{array}{l}\text { - At the end of 2nd day after } \\
\text { application }\end{array}$ & 21 & 35.0 & 19 & 31.7 & 13 & 21.7 & 30 & 50.0 & 31 & 51.7 & 31 & 51.7 & 2.762 & 0.097 & 4.937 & $0.026^{*}$ & 11.627 & $0.001 *$ \\
\hline
\end{tabular}


Table (5): Continue.

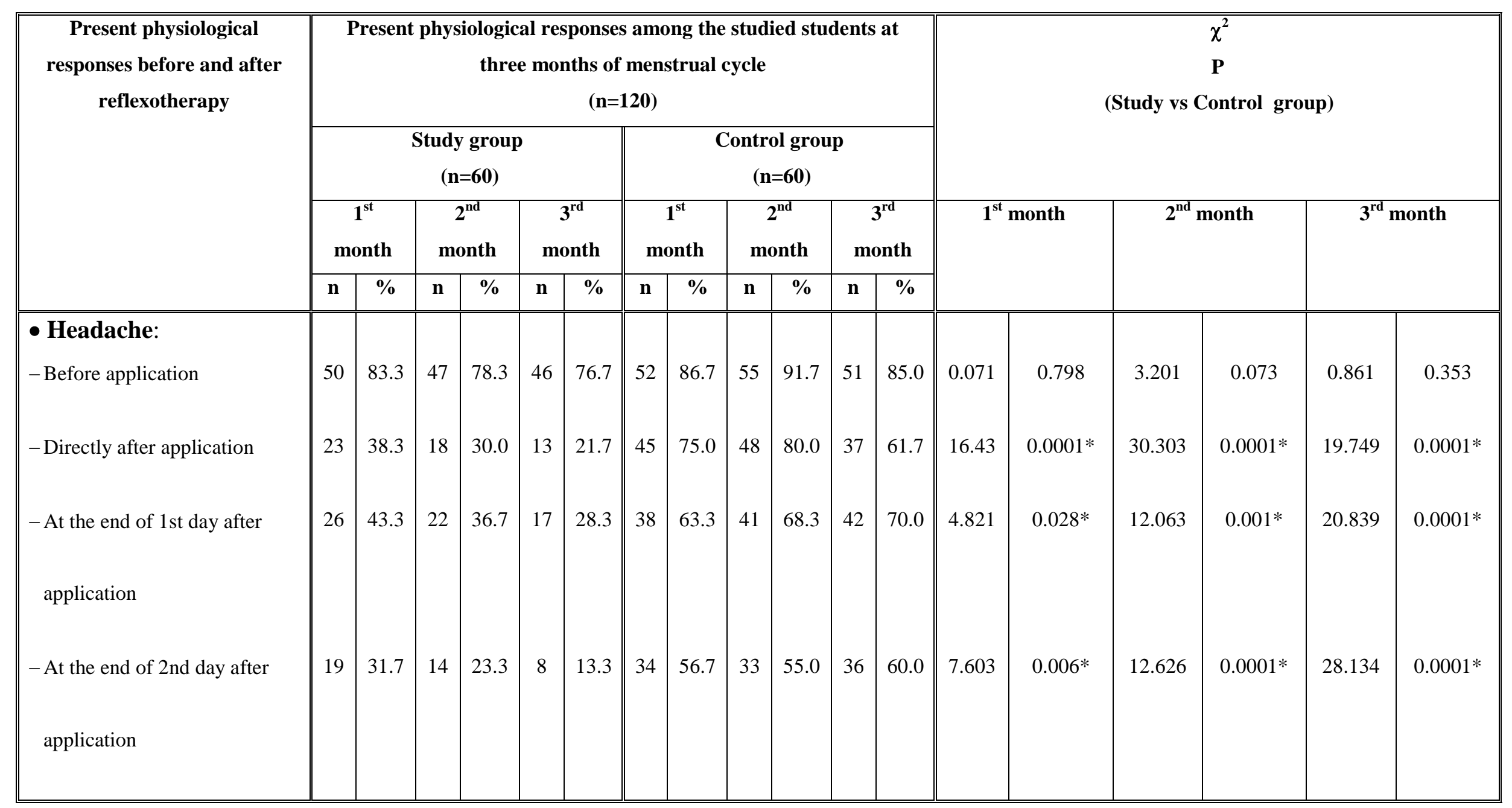

Vol.14 No.1 May, 2018 
Table (6): Total score level of behavioral response to menstrual pain among the studied students at three months of menstrual cycle before and after application of reflexotherapy.

\begin{tabular}{|c|c|c|c|c|c|c|c|c|c|c|c|c|c|c|c|}
\hline \multirow{4}{*}{$\begin{array}{c}\text { Levels of total behavioral response to } \\
\text { menstrual pain before and after } \\
\text { reflexotherapy }\end{array}$} & \multicolumn{12}{|c|}{$\begin{array}{l}\text { Behavioral response to menstrual pain among the studied students at three } \\
\text { months of menstrual cycle }(n=120)\end{array}$} & \multirow{2}{*}{\multicolumn{3}{|c|}{$\begin{array}{c}\chi^{2} \\
\mathbf{P} \\
\text { (Study vs Control group) }\end{array}$}} \\
\hline & \multicolumn{6}{|c|}{$\begin{array}{c}\text { Study group } \\
(\mathrm{n}=60)\end{array}$} & \multicolumn{6}{|c|}{$\begin{array}{c}\text { Control group } \\
(\mathbf{n}=\mathbf{6 0})\end{array}$} & & & \\
\hline & \multicolumn{2}{|c|}{$1^{\text {st }}$ month } & \multicolumn{2}{|c|}{$2^{\text {nd }}$ month } & \multicolumn{2}{|c|}{$3^{\text {rd }}$ month } & \multicolumn{2}{|c|}{$1^{\text {st }}$ month } & \multicolumn{2}{|c|}{$2^{\text {nd }}$ month } & \multicolumn{2}{|c|}{$3^{\text {rd }}$ month } & \multirow{2}{*}{$\begin{array}{c}1^{\text {st }} \\
\text { month }\end{array}$} & \multirow{2}{*}{$\begin{array}{c}2^{\text {nd }} \\
\text { month }\end{array}$} & \multirow{2}{*}{$\begin{array}{c}3^{\text {rd }} \\
\text { month }\end{array}$} \\
\hline & $\mathbf{N}$ & $\%$ & $\mathbf{N}$ & $\%$ & $\mathbf{n}$ & $\%$ & $\mathbf{n}$ & $\%$ & $\mathbf{N}$ & $\%$ & $\mathbf{N}$ & $\%$ & & & \\
\hline $\begin{array}{l}\text { Before application: } \\
-\quad \text { Mild pain } \\
-\quad \text { Moderate pain } \\
-\quad \text { Severe pain } \\
\end{array}$ & $\begin{array}{c}4 \\
54 \\
2\end{array}$ & $\begin{array}{l}6.7 \\
90.0 \\
3.3\end{array}$ & $\begin{array}{c}3 \\
54 \\
3\end{array}$ & $\begin{array}{c}5.0 \\
90.0 \\
5.0\end{array}$ & $\begin{array}{c}4 \\
50 \\
6\end{array}$ & $\begin{array}{c}6.7 \\
83.3 \\
10.0 \\
\end{array}$ & $\begin{array}{c}6 \\
53 \\
1 \\
\end{array}$ & $\begin{array}{c}10.0 \\
88.3 \\
1.7\end{array}$ & $\begin{array}{c}4 \\
53 \\
3\end{array}$ & $\begin{array}{c}6.7 \\
88.3 \\
5.0 \\
\end{array}$ & $\begin{array}{c}6 \\
51 \\
3\end{array}$ & $\begin{array}{c}10.0 \\
85.0 \\
5.0\end{array}$ & $\begin{array}{l}0.743 \\
0.690\end{array}$ & $\begin{array}{l}0.710 \\
0.702\end{array}$ & $\begin{array}{l}1.410 \\
0.494\end{array}$ \\
\hline $\begin{array}{l}\text { Directly after application: } \\
-\quad \text { No pain } \\
-\quad \text { Mild pain } \\
-\quad \text { Moderate pain } \\
-\quad \text { Severe pain }\end{array}$ & $\begin{array}{c}9 \\
24 \\
16 \\
11\end{array}$ & $\begin{array}{l}15.0 \\
40.0 \\
26.7 \\
18.3\end{array}$ & $\begin{array}{c}10 \\
50 \\
0 \\
0\end{array}$ & $\begin{array}{c}1.7 \\
98.3 \\
0 \\
0\end{array}$ & $\begin{array}{c}16 \\
44 \\
0 \\
0\end{array}$ & $\begin{array}{c}26.7 \\
73.3 \\
0 \\
0\end{array}$ & $\begin{array}{c}0 \\
8 \\
13 \\
39\end{array}$ & $\begin{array}{c}0 \\
13.3 \\
21.7 \\
65.0\end{array}$ & $\begin{array}{c}0 \\
12 \\
27 \\
21\end{array}$ & $\begin{array}{c}0 \\
20.0 \\
45.0 \\
35.0\end{array}$ & $\begin{array}{c}0 \\
16 \\
24 \\
20\end{array}$ & $\begin{array}{c}0 \\
26.7 \\
40.0 \\
33.3\end{array}$ & $\begin{array}{c}29.890 \\
0.0001 *\end{array}$ & $\begin{array}{c}81.290 \\
0.0001^{*}\end{array}$ & $\begin{array}{c}98.880 \\
0.0001 *\end{array}$ \\
\hline $\begin{array}{l}\text { At the end of } \mathbf{1}^{\text {st }} \text { day after application } \\
-\quad \text { No pain } \\
-\quad \text { Mild pain } \\
-\quad \text { Moderate pain } \\
-\quad \text { Severe pain }\end{array}$ & $\begin{array}{c}9 \\
22 \\
15 \\
14\end{array}$ & $\begin{array}{l}15.0 \\
36.7 \\
25.0 \\
23.3\end{array}$ & $\begin{array}{c}14 \\
40 \\
6 \\
0\end{array}$ & $\begin{array}{c}23.3 \\
66.7 \\
10.0 \\
0\end{array}$ & $\begin{array}{c}12 \\
48 \\
0 \\
0\end{array}$ & $\begin{array}{c}20.0 \\
80.0 \\
0 \\
0\end{array}$ & $\begin{array}{c}0 \\
7 \\
18 \\
35 \\
\end{array}$ & $\begin{array}{c}0 \\
11.7 \\
30.0 \\
58.3\end{array}$ & $\begin{array}{c}0 \\
7 \\
27 \\
26 \\
\end{array}$ & $\begin{array}{c}0 \\
11.7 \\
45.0 \\
43.3 \\
\end{array}$ & $\begin{array}{c}0 \\
8 \\
27 \\
25\end{array}$ & $\begin{array}{c}0 \\
13.3 \\
45.0 \\
41.7\end{array}$ & $\begin{array}{c}55.010 \\
0.0001 *\end{array}$ & $\begin{array}{c}83.781 \\
0.0001^{*}\end{array}$ & $\begin{array}{c}108.71 \\
0.0001 *\end{array}$ \\
\hline $\begin{array}{l}\text { At the end of } \mathbf{2}^{\text {nd }} \text { day after application } \\
-\quad \text { No pain } \\
-\quad \text { Mild pain } \\
-\quad \text { Moderate pain }\end{array}$ & $\begin{array}{l}12 \\
34 \\
14\end{array}$ & $\begin{array}{l}20.0 \\
56.7 \\
23.3\end{array}$ & $\begin{array}{c}20 \\
34 \\
6\end{array}$ & $\begin{array}{l}33.3 \\
56.7 \\
10.0\end{array}$ & $\begin{array}{c}22 \\
38 \\
0\end{array}$ & $\begin{array}{c}36.7 \\
63.3 \\
0\end{array}$ & $\begin{array}{c}0 \\
8 \\
52\end{array}$ & $\begin{array}{c}0 \\
13.3 \\
86.7\end{array}$ & $\begin{array}{c}0 \\
8 \\
52\end{array}$ & $\begin{array}{c}0 \\
13.3 \\
86.7\end{array}$ & $\begin{array}{c}0 \\
4 \\
56\end{array}$ & $\begin{array}{c}0 \\
6.7 \\
93.3\end{array}$ & $\begin{array}{c}49.970 \\
0.0001 *\end{array}$ & $\begin{array}{c}72.580 \\
0.0001^{*}\end{array}$ & $\begin{array}{l}105.420 \\
0.0001 *\end{array}$ \\
\hline
\end{tabular}

*Significant $(\mathbf{P}<\mathbf{0 . 0 5})$ 


\section{Discussion}

The results of the present study revealed that the prevalence rate of primary dysmenorrhea was found to be about $85.6 \%$ among all students of the second year Faculty Nursing students at Tanta University. This finding is strongly agreed with Abo-Hatab T (2017), ${ }^{(20)}$ who noted high prevalence rate of primary dysmenorrhea reaching $87.5 \%$ in Tanta city, and Kamel MD et al.,(2017) ${ }^{(21)}$ as well who mentioned that the prevalence of primary dysmenorrhea was $84.01 \%$ in Egypt. Concerning socio-demographic characteristics of the studied students (study and control groups), the results of the present study revealed that the two groups were homogeneous based on the variables such as age, residence and body mass index. The present study clarified that more than half of the study and control groups had menarche at $13-<15$ years. This result is similarly supported by Shaban R (2011) ${ }^{(22)}$ and Ameade E et al., (2016), ${ }^{(23)}$ who demonstrated that more than half of the students had reached menarche at $13-15$ years. As regard the interval of the menstrual cycle, the present study indicated that more than half of students had an interval of >27-35days. This result is pertained with Gumanga SK et al (2012) ${ }^{(24)}$ and Nooh AM (2015) ${ }^{(25)}$ who displayed that, the interval of the menstrual cycle ranged between 21 and 35 days with a mean length of $27.9 \pm 0.9$ days. The present study also revealed that more than three fifth of the study and the control groups had duration of menstrual blood flow ranged from >5-7 days. This result aligns with Omidvar S et al., (2012) ${ }^{(26)}$ who revealed that, the duration of menstruation among $70.5 \%$ of subjects was 6 days. On the other hand, Shaban R (2011) ${ }^{(22)}$ revealed that, it took 4 days for the menstrual flow to stop.

In addition, the current study demonstrated that more than half of the study and control groups described the amount of their menstrual blood loss as moderate (2-3 towels/day). This finding is strongly in concurrence with Abo-Hatab T (2017) ${ }^{(20)}$ and Shaban R (2011) ${ }^{(22)}$ who proclaimed that more than half of the students had moderate menstrual flow and they were changing 2-3 pad/day. Referring to the intensity of dysmenorrhea among the study and control groups, the current study revealed that slightly more than three fifth of the study group and two third of the control group had severe degree of dysmenorrhea. This result acquainted with Ali NF (2011) (27) and Shaban $R$ (2011) (22), who demonstrated that the majority of the students had severe and unbearable pain. Regarding the onset of menstrual pain occurrence, nearly two third of the students of both groups had reported that the pain was started with the onset of menstruation 
and continue for 48 hours. This result is supported by Gagua T et al.,(2012) ${ }^{(28)}$ and AlYousef S et al., (2013) ${ }^{(29)}$ who accounted that more than one third of students had reported that pain was started with the beginning of the menstrual cycle and lasted for 48 hours.

Primary dysmenorrhea (PD) is defined as cramping pain in the lower abdomen occurring just before or during menstruation. The present study revealed that nearly two third of the study group and more than half of the control group had felt menstrual pain on lower abdomen. This result is corresponding to Shahr-jerdy $\mathbf{S}$ et al., (2012) ${ }^{(30)}$ who indicated that nearly one half of the students of both experimental and control groups reported pain in the lower abdomen. Concerning the previous coping methods utilized by the students to alleviate primary dysmenorrhea, the current study showed that the majority of the students used bed rest, drinking warm water, keeping warm and taking analgesics in order. These results are congruent with Wu BK (2009) (31) and Al Yousef S et al., (2013) ${ }^{(29)}$, who demonstrated that bed rest, hot fluids, application of warm compresses and analgesics were the most frequently strategies used in the self-management of dysmenorrhea. In relation to the intensity of menstrual pain, the results of the present study demonstrated that reflexotherapy was effective in reducing menstrual pain intensity. Where there was a significant reduction of pain intensity as measured by Visual Analogue Scale (VAS) among the study group compared to control group $1^{\text {st }}$, $2^{\text {nd }}$ and $3^{\text {rd }}$ months after the application of reflexotherapy. This was so obvious at the third month post intervention where the mean scores of menstrual pain intensity were (6.93 and 7.13 respectively) among the study group and the control group preintervention and decreased post intervention to (1.85) among the study group compared to(4.62) among the control group. These results are consistent with Valiani et al., (2010) ${ }^{(11)}$, who compared the impacts of reflexology and ibuprofen on dysmenorrhea among students. The results showed that the sedative effects of reflexology continued even after the end of intervention at the third cycle. The effect of reflexotherapy in reducing intensity of primary dysmenorrhea can be explained in the light of gate control theory. Reflexotherapy as a non-painful input closes the "gates" to painful input (menstrual pain), this prevents pain sensation from traveling to the central nervous system and hence pain perception is inhibited.

Again, the present study revealed that reflexotherapy is significantly reduced the quality of menstrual pain. Where pain quality refers to how one feels pain or 
describe it in words that indicate the pain's nature. This study assessed the intensity of menstrual pain in students' words whether it was sensory or affective description using the Short form of Modified McGill Pain Questionnaire (MPQ-SF). The finding of the present study revealed that reflexotherapy is significantly reduced the pain intensity score of the sensory and affective menstrual pain descriptors. These findings are identical with Valiani et al., (2010) ${ }^{(11)}$ who illustrated that there was statistically significant difference between the two groups regarding the sensory and affective pain dimensions in McGill questionnaire after the intervention with reflexology.

An interesting finding in this study is that the application of reflexotherapy has improved most of students' physiological responses to menstrual pain. There was statistically significant improvement in physical symptoms from pre to post application of reflexotherapy group as regard headache, fatigue, muscle pain ,nausea and insomnia. This finding was matched with an exploratory study of reflexological treatment for headache which revealed that through three months follow up after reflexology treatment, $81 \%$ of patients were cured from their headache problem and that $19 \%$ of patients who had formerly taken drugs to control their headaches were able to stop medication support following participation in this study ${ }^{(32)}$.Tarrasch $\mathbf{R}$ et al (2017) ${ }^{(33)}$, also reported that reflexology significantly ameliorated fatigue and quality of sleep in breast cancer patients during radiation therapy. This can be attributed to the benefits of reflexotherapy in alleviating the effects of stress associated with primary dysmenorrhea. Furthermore, Ray BS et al., (2017) ${ }^{(34)}$ revealed that reflexology is effective in reducing muscle pain and improving muscle comfort by enhancing blood flow which stimulates parasympathetic nervous system. Goweily $\mathbf{E}$ (2015) ${ }^{35)}$, who examined the effect of reflexology on first stage labour pains, had shown that nausea and vomiting had decreased after the application of reflexology sessions. The effects of reflexotherapy on reducing physiological responses to menstrual pain in the present study were also supported by literature review which postulated that reflexotherapy can affect the body as a whole. It works through each organ, gland and body system. Considering total score levels of behavioral responses to menstrual pain. The present study illustrated that the majority of both groups had moderate degree of behavioral responses to dysmenorrheal pain pre intervention whereas, post intervention it was evident that reflexotherapy is 
significantly reduced the total score levels of behavioral responses to menstrual pain. This finding was consistent with Goweily $\mathbf{E}$ (2015) ${ }^{(35)}$ who showed that there was a significant decrease in behavioral pain scale after reflexology session among the study subjects.

The results of this study suggesting that faculty nursing students can gain a noticeable relief from primary dysmenorrhea by application of reflexotherapy. This is related to its effect in helping the body to activate its healing power by releasing the energy blocked in certain parts of the body through special massage movements applied to the feet.

\section{Conclusion}

Reflexotherapy significantly decreases the intensity of menstrual pain. It is significantly improves the sensory and affective menstrual pain descriptors as well as improves the physiological and behavioral responses to menstrual pain among study group that are more profound three months post intervention compared to control group. Hence it can be concluded that reflexotherapy is useful in controlling primary dysmenorrhea.

\section{Recommendation}

Based on the findings of the current study, the following recommendations are derived and suggested:
1. Incorporating reflexotherapy as a complementary and alternative therapy into the nursing curriculum and nursing practice to relieve primary dysmenorrhea and its related symptoms.

2. Developing in-service training program for nurses about reflexotherapy to relieve primary dysmenorrhea, in order to improve their knowledge and enable them to impart this knowledge to female adolescent suffering from primary dysmenorrhea.

3. Mass media should be utilized for dissemination of simple, correct and relevant information about reflexotherapy as a complementary and alternative therapy for the management of primary dysmenorrhea as well as other types of pain.

\section{References}

1. Nag U., and Kodali M.Effect of Yoga on Primary Dysmenorrhea and Stress in Medical Students, Journal of Dental and Medical Sciences, 2013; 4(1): 69-73.

2. Kashefi F., Khajehei M., Cher M T., Alavinia M., and Asili J. Comparison of the Effect of Ginger and Zinc Sulfate on Primary Dysmenorrhea: A PlaceboControlled Randomized Trial, Journal of Pain Management Nursing, 2014; 15(4): 826-33. 
3. Mahvash N., Eidy A., Mehdi K., Zahra MT., Mani M., and Shahla H. The Effect of Physical Activity on Primary Dysmenorrhea of Female University Students, World Applied Sciences Journal, 2012: 17 (10); 1246-52.

4. Ferri FF. Ferri's Clinical Advisor, USA, Elsevier com., 2017; 395.

5. Deepa R. Ginger Rhizome Powder on Dysmenorrhea, International Journal of Advances in Nursing Management, 2016; 4(4): 417-22.

6. Gumanga SK., and Kwame- Aryee R. Prevalence and Severity of Dysmenorrhoea among Some Adolescent Girls in A Secondary School in Accra Ghana, Postgraduate Medical Journal of Ghana, 2012; 1 (1).

7. Seller RH., and Symons AB. Differential Diagnosis of Common Complaints, $6^{\text {th }}$ ed., China, Elsevier Saunders com., 2012; 248.

8. Calis KA. Dysmenorrhea Treatment \& Management, Available from http://emedicine.medsacpe.com/article/2 53812-treatment Retrieved at 22-12016.

9. Bokaie M., Farajkhoda T., Enjezab B., Khoshbin A., and Mojgan KZ. Oral Fennel (FoeniculumVulgare) Drop Effect on Primary Dysmenorrhea: Effectiveness of Herbal Drug, Iranian Journal of Nursing and Midwifery
Research, 2013; 18 (2): 128-32.

10 Yang M., Chen X., Bo L., Lao L., Chen J., Yu S., Yu Z., Tang, Ling H., Wu X., Yang J., and Liang F. Moxibustion for Pain Relief in Patients with Primary Dysmenorrhea: A Randomized Controlled Trial,PLoS ONE， 2017;12(2): e0170952. https:/ /doi.org/10.1371/journal.pone.0170952

11 Valiani M., Babaei E., Heshmat R., and Zare Z. Comparing the Effects of Reflexology Methods and Ibuprofen Administration on Dysmenorrhea in Female Students of Isfahan University of Medical Sciences, Iranian Journal ofNursing Midwifery Research, 2010; 15 (11): 371-78.

12 Tom MI., Palaz A., Martínez Damian., Navarro F., and Gil-Guill VF.Factors Associated with Increased Pain in Primary Dysmenorrhea: Analysis Using a Multivariate Ordered Logistic Regression Model, Journal of PediatrAdolescGynecol, 2017; 30: 199202.

13 Gozuyesil E., and Baser M. The Effect of Foot Reflexology Applied to Women Aged Between 40 and 60 on Vasomotor Complaints and Quality of Life, Journal of Complementary Therapies in Clinical Practice, 2016; 24 : 78-85.

14 Atkins R., and Harris P. Using 
reflexology to manage stress in the workplace: A preliminary study, Journal of Complementary Therapies in Clinical Practice, 2008: 14; 280-87.

15 Dolatian M., Hasanpour A., Montazeri SH., Heshmat R., and Majd A. The Effect of Reflexology on Pain Intensity and Duration of Labor on Primiparas, Iranian Red Crescent Medical Journal, 2011: 13(7); 475-79.

16 Tse H. Sole Guidance: Ancient Secrets of Chinese Reflexology to Heal the Body, Mind, Spirit, USA, Hay House Publishers Com., 2016; 14.

17 Hasoun S. Reflexology in Pain and Illness, Unpublished Master Dissertation, Faculty of Medicine, Mansoura University, 2009; 2.

18 AbdELhaleem S. Effect of Foot Massage on Relieving Mother's Post Cesarean Section incisional Pain, International Academic Research for Multidisciplinary Journal, 2013; 1(7): 202-213.

19 Belal GH. Efficacy of Acupressure on Pain Intensity during First Stage of Labor, Unpublished Doctorate Dissertation, Faculty of Nursing, Tanta University, 2006;27.

20 Abo-Hatab T. Efficacy of Lavender Oil Massage on Relieving Primary Dysmenorrhea among First Year Faculty Nursing Students, Unpublished
Master Dissertation, Faculty of Nursing, Tanta University, 2017; 45-9, 88,93 .

21 KamelDM.,Tantawy SA., And Abdelsamea GA.Experience of Dysmenorrhea among A Group of Physical Therapy Students from Cairo University: An Exploratory Study, Journal of Pain Research, 2017; 10: 1079-85.

22 Shaban R. Comparative Study Between Three Different Techniques on Relieving Dysmenorrhea among Students of Faculty of Nursing at Tanta University, Unpublished Doctorate Dissertation, Faculty of Nursing, Tanta University, 2011; 54.

23 Ameade EPK., and Garti HA. Age at Menarche and Factors that Influence It: A Study among Female University Students in Tamale, Northern Ghana. PLoS ONE, 2016; 11(5): e0155310. https://doi.org/10.1371/journal.pone.015 5310

24 GumangaSK., and Kwame-Aryee RA. Menstrual Characteristics in Some Adolescent Girls in Accra, Ghana. Ghana Medical Journal, 2012;46(1):3-7.

25 Nooh AM. Menstrual Disorders among Zagazig University Students, Zagazig, Egypt, Middle East Fertility Society Journal, 2015; 20: 198-203

26 Omidvar S, Esmailzadeh S, 
Baradaran M, and BasiratZ. Effect of Fennel on Pain Intensity in dysmenorrhoea: A Placebo ControlledTrial, An International Quarterly Journal of Research in Ayurveda, 2012; 33(2): 311-13.

27 Ali NF. Complementary Therapies That are Used for the Relief of Dysmenorrhea among Zagazig Technical Health Institute Students, Tanta Scientific Nursing Journal, 2011; 1(1): 25-43.

28 Gagua T., Tkeshelashvili B., and Gagua D.Primary dysmenorrhea: prevalence in adolescent population of Tbilisi, Georgia and risk factors, Journal of the Turkish- German Gynecological Association, 2012; 13(3): 162-68.

29 AlYousefSA.,Abd El-Hay SA., Mohamed NS., and Abo Baker LRM. Effect of Transcutaneous Electrical Nerve Stimulation (TENS) on the Relief of Dysmenorrheal Pain among Students of Applied Medical Science College at Hafer Al-Batin, Journal of American Science 2013;9(11): 225-34.

\section{Shahr-jerdy S., Hosseini RS., Eivazi}

M. Effects of Stretching Exercises on Primary Dysmenorrhea in Adolescent Girls, Journal of Biomedical Human Kinetics, 2012; 4: 127 -32.

31 Wu BK. Effect of foot reflexology on dysmenorrhoea in adolescents: A randomized controlled trial in Taiwan, Published Doctorate Dissertation, the School of Nursing and Midwifery in Griffith Health, Griffith University, 2009; 6-7.

32 LaunsoL., and Arnberg S.An Exploratory Study of Reflexological Treatment for Headache, Journal of Alternative Nursing, 1999; 5(3):57.

\section{Tarrasch R., Carmel-Neiderman NN.,} Ben-Ami S., Kaufman B., Pfeffer R., Ben-David M., and Gamus D.The Effect of Reflexology on the PainInsomnia-Fatigue Disturbance Cluster of Breast Cancer Patients During Adjuvant Radiation Therapy. Journal of Alternative and Complementary Medicine, 2017.

34 Ray BS YS., Natha $H$ and Nageshwar V. Foot Reflexology : Effect on Pain and Anxiety in Post Oprative Patient, International Education Research Journal, 2017; 3(5):21-7.

35 Goweily E.Efficacy of Reflexology on First Stage Labour Pains, Journal of Health, Medicine and Nursing, 2015;18:53-64. 